\title{
Kinetics of Transesterification of Croton megalocarpus Oil Using Alkaline Earth Catalysts with Conventional and Microwave Heating
}

\author{
Anil Kumar (iD) and Henry K. Kiriamiti \\ Department of Chemical \& Process Engineering, Moi University, Eldoret 30100, Kenya \\ Correspondence should be addressed to Anil Kumar; akumar@mu.ac.ke
}

Received 30 July 2020; Revised 20 September 2020; Accepted 25 October 2020; Published 16 November 2020

Academic Editor: Maciej Jaskulski

Copyright (c) 2020 Anil Kumar and Henry K. Kiriamiti. This is an open access article distributed under the Creative Commons Attribution License, which permits unrestricted use, distribution, and reproduction in any medium, provided the original work is properly cited.

\begin{abstract}
Transesterification kinetics of Croton megalocarpus oil to produce fatty acid methyl esters (FAME) was studied using homogeneous $\mathrm{NaOH}$ and heterogeneous alkaline earth $\mathrm{Nano} \mathrm{MgO}, \mathrm{MgO}$, Nano $\mathrm{CaO}, \mathrm{CaO}$, Reoxidized $\mathrm{CaO}, \mathrm{SrO}$, and $\mathrm{BaO}$ catalysts. Characteristic surface, bulk, and chemical properties of the heterogeneous catalysts were obtained which included surface area, pore properties, scanning electron micrography, X-ray diffraction, basic strength, and basicity. The catalyst porosity varied as Nano $\mathrm{MgO}>\mathrm{Nano} \mathrm{CaO}>\mathrm{MgO}>\mathrm{CaO}>\mathrm{CaO}-\mathrm{RO}>\mathrm{SrO}>\mathrm{BaO}$ and basicity as $\mathrm{BaO}>\mathrm{SrO}>\mathrm{Nano} \mathrm{CaO}>\mathrm{CaO} \mathrm{RO}>\mathrm{CaO}>\mathrm{Nano}$ $\mathrm{MgO}>\mathrm{MgO}$. Catalysts $\mathrm{NaOH}, \mathrm{BaO}, \mathrm{SrO}$, and $\mathrm{Nano} \mathrm{CaO}$ gave a good FAME yield ( $>50 \%)$, and reaction order and rate constant have been reported for these catalysts, for both conventional heating and microwave irradiation. The overall reaction for $\mathrm{NaOH}$ was of $1^{\text {st }}$ order for microwave irradiation with respect to triglyceride and of $2^{\text {nd }}$ order with respect to triglyceride under conventional heating. For the heterogeneous catalysts, the overall reaction was of $3^{\text {rd }}$ order, $2^{\text {nd }}$ order with respect to triglyceride and $1^{\text {st }}$ order with respect to methanol for both heating methods. Reaction rate constants for microwave irradiation were higher than those for conventional heating due to faster reaction rates under such heating. $\mathrm{BaO}$ was the most active heterogeneous catalyst, followed by $\mathrm{SrO}$ and $\mathrm{Nano} \mathrm{CaO}$, which was in accordance with their basicity.
\end{abstract}

\section{Introduction}

Biodiesel is a biofuel obtained from renewable sources having the potential to replace petrodiesel. It is considered to be a green fuel being carbon neutral and free from $\mathrm{N}$ and S [1]. Croton megalocarpus tree is indigenous to East Africa, with large scale plantations and no adverse ecological farming effects [2]. Croton megalocarpus oil is nonedible and has been shown to have the highest potential as a biodiesel feedstock in East Africa [3, 4]. Biodiesel is usually produced by reacting an alcohol with an oil/fat (triglyceride) in the presence of a catalyst, the reaction called transesterification. The overall reversible reaction (Equation 1) is given in Figure 1 [5]. When the reactant alcohol is methanol, the product is fatty acid methyl esters (FAME).
Catalysts used in transesterification are homogeneous (Brønsted acids and bases, biocatalysts, and nonionic organics) and heterogeneous (acidic and basic). Homogenous catalysts are easy to use and economical and in many instances give better conversion. However, they are miscible in reaction media, are not recovered, and require complex postreaction treatment that has environmental issues. Heterogeneous catalysts do not dissolve in the reacting system and can be recovered and recycled, but they are highly selective and activity depends upon their surface properties [6]. Heterogeneous catalysts are acid type and base type. Solid acid catalysts are suited to oils with high free fatty acid (FFA) contents as they catalyze both esterification (converts free fatty acid into corresponding ester) and transesterification reactions $[7,8]$. Such catalysts show weak catalytic activity, usually requiring a long reaction time and a 


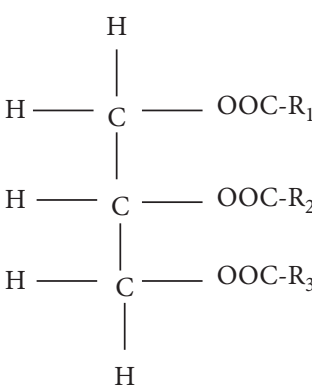

Triglyceride

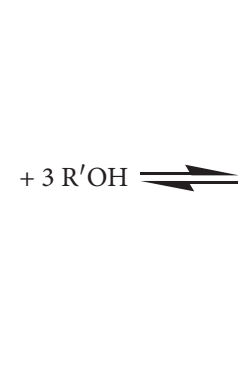

Alcohol

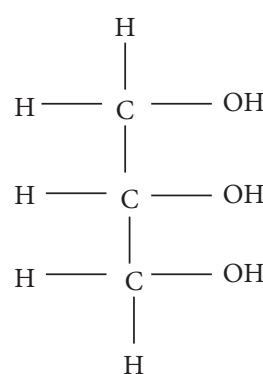

Glycerol
$\mathrm{R}_{1}$-COO-R

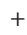

$\mathrm{R}_{2}$-COO-R'

$+$

$\mathrm{R}_{3}-\mathrm{COO}-\mathrm{R}^{\prime}$

Fatty acid esters

Figure 1: Transesterification reaction for biodiesel.

high reaction temperature, and are sensitive to the presence of water $[9,10]$. Heterogeneous basic catalysts have a higher reaction rate [11], due to the formation of a highly active alkoxide ion $\left(\mathrm{RO}^{-}\right)$which catalyzes the reaction [12]. Heterogeneous basic catalysts give a lower yield when used with oils with high FFA (>2\%) due to soap formation [13]. Basic catalysts have been categorized as single-component metal oxides, zeolites, supported alkali metal, clay minerals, and nonoxides [14]. Alkaline earth catalysts $\mathrm{BaO}, \mathrm{SrO}, \mathrm{CaO}$, and $\mathrm{MgO}$ belong to single-component metal oxides. Alkaline earth oxides have been used to transesterify a variety of oils and fats. $\mathrm{CaO}$ and $\mathrm{MgO}$ were used to transesterify $J$ curcas [15], sunflower oil using $\mathrm{MgO}$ and $\mathrm{CaO}$ [16], soybean oil using $\mathrm{MgO}, \mathrm{CaO}, \mathrm{SrO}$, and $\mathrm{BaO}$ [17-19], soybean oil over $\mathrm{CaO}$ catalyst [20-22], rapeseed oil using $\mathrm{MgO}$ and $\mathrm{CaO}$ $[23,24]$, Camelina sativa using $\mathrm{MgO}, \mathrm{CaO}, \mathrm{SrO}$, and $\mathrm{BaO}$ [9], palm oil using $\mathrm{MgO}, \mathrm{CaO}, \mathrm{SrO}$, and $\mathrm{BaO}$ [25], waste cooking oil using $\mathrm{CaO}$ [20], poultry fat using $\mathrm{CaO}[26,27]$, and palm olein using $\mathrm{CaO}$ [28]. These studies have used conventional heating and pressure being atmospheric and above. Khemthong et al. [29] and Patil et al. [30] used microwave irradiation for transesterification of Palm olein using $\mathrm{CaO}$ and Camelina sativa oil using $\mathrm{MgO}, \mathrm{SrO}$, and $\mathrm{BaO}$ catalysts, respectively. Waste cooking oil was transesterified using $\mathrm{BaO}$ under simultaneous microwave and ultrasound irradiations [31]. This paper reports reaction kinetics for transesterification of Croton megalocarpus oil with methanol to produce FAME using alkaline earth oxides, $\mathrm{BaO}, \mathrm{SrO}, \mathrm{CaO}$, Nano $\mathrm{CaO}$, Reoxidized $\mathrm{CaO}$ ( $\mathrm{CaO} \mathrm{RO}$ ), $\mathrm{MgO}$, and Nano $\mathrm{MgO}$, by conventional heating and microwave heating.

Reactions with homogeneous catalysts have been studied extensively and the observed reaction rates show a lot of variance. Complications arise due to mass transfer limitations in the two-phase reacting system. One of the earliest pioneering work on homogeneous reaction kinetics is that of Noureddini and Zhu [32] for transesterification of soybean oil using $\mathrm{NaOH}$ catalyst. Differential reaction rates for the three-step reactions were correlated with experimental data and reaction rate constants, and activation energies, for forward and reverse reactions obtained. Initial reaction rates were slow and it was due to mass transfer limitations. The reaction rate increased with mixing intensity (Reynolds number) in this region of slow reaction. A second phase was when the reaction becomes fast and was kinetics controlled.
Kinetics was of second order and mixing Reynolds number had little effect in this region. A third phase was when the reactions slow down once again which was attributed to an equilibrium state where reverse reactions come into play. Darnoko and Cheryan [33] observed a pseudo-second-order reaction in the first 30 minutes, and first- or zero-order in the later part for transesterification of palm oil using $\mathrm{KOH}$ catalyst. An integrated form of rate equations based on triglyceride, diglyceride, and monoglyceride concentrations was used for data analysis and forward reaction rate constants and activation energies for the three-step reactions have been reported. In a similar study of palm oil transesterification [34], it was observed that reverse reactions were insignificant, and, at high mixing intensity (Reynold number $=2000$ ), the mass transfer controlled region was negligible. A second-order reaction was observed, and forward and reverse reaction rate constants for the threestep reaction were obtained. Transesterification kinetics of sunflower with methanol was studied by Vicente et al. [35] and Bambase et al. [36] and with ethanol by Marjanović et al. [37]. Vicente et al. [35] included the catalyst (KOH) concentration in the reaction rate by defining an effective rate constant which was a multiple of catalyst concentration and the rate constant. This unconventional approach to kinetics resulted in a second-order reaction kinetics. Reaction rate constants and energies of activation were reported. Bambase et al. [36] used $\mathrm{NaOH}$ catalyst and observed a second-order rate. Mass transfer limitations were minimal for stirring speeds of 400-600 rpm. Reaction rate constants for forward and reverse three-step reactions were reported. Marjanović et al. [37] used $\mathrm{NaOH}$ catalyst and reported reaction kinetics for the overall reaction. Mass transfer limitations were neglected. Initial reaction phase was modelled as irreversible second order and the later phase as a reversible second order. Similar results are reported for the methanolysis of sunflower oil using $\mathrm{KOH}$ catalyst by Stamenković et al. [38] at low temperatures of $283-303 \mathrm{~K}$, using the overall reaction. Jain and Sharma [39] studied the two-stage esterification/ transesterification of Jatropha curcas oil with methanol using $\mathrm{H} 2 \mathrm{SO} 4 / \mathrm{NaOH}$ catalysts. They used the overall reaction and obtained a first-order reaction rate for both stages. Reaction rate constants for both the stages are reported. Jain et al. [40] studied the two-stage esterification/transesterification of waste cooking oil with methanol using $\mathrm{H} 2 \mathrm{SO} 4 / \mathrm{NaOH}$ catalysts. They used the overall reaction and observed a first- 
order reaction rate for both stages. Reaction rate constants for both the stages were reported. A supercritical noncatalytic and homogeneous catalytic using $\mathrm{KOH}$, transesterification of Croton megalocarpus oil with methanol, gave a first-order reaction for the overall reaction [41]. These kinetic studies on soybean oil, sunflower oil, palm oil, Jatropha curcas oil, waste cooking oil, and Croton megalocarpus oil show that the observed reaction order varied from zero to two. Initially, the reaction system consists of two phases and mass transfer controls, but very soon the reaction system becomes pseudo-homogeneous and chemical reaction becomes rate controlling. Initial studies focussed on detailed reaction kinetics for the three reaction steps which yields reaction rate constants for forward and reaction rates and activation energies for the three reactions. Heterogeneous catalysts form a three-phase system. Studies of reaction kinetics using alkaline earth catalysts have been limited. Dossin et al. [42, 43] studied kinetics of transesterification of ethyl acetate with methanol over $\mathrm{MgO}$ catalyst. Transesterification kinetics of soybean oil over $\mathrm{MgO}, \mathrm{CaO}$, and $\mathrm{BaO}$ catalysts was studied by Singh and Fernando [44]. Veljković et al. [19] studied the methanolysis kinetics of sunflower oil catalyzed by $\mathrm{CaO}$. Patil et al. [30] studied transesterification kinetics of Camelina sativa oil over $\mathrm{BaO}, \mathrm{CaO}, \mathrm{MgO}$, and $\mathrm{SrO}$ catalysts, using conventional and microwave heating. Microwave heating is an energyefficient, quick heating process for transesterification as compared to conventional convectional heating [45].

A general rate equation has been developed [30, 44] which can take care of varying reaction orders with respect to methanol and triglyceride. This rate equation is applicable to both homogeneous and heterogeneous catalyst systems since it is based on the overall reaction. Overall stoichiometry is written for a forward reaction, assuming a negligible reverse reaction, where $A, B, R$, and $S$ represent triglyceride, alcohol, fatty acid ester, and glycerol, respectively.

Overall reaction:

$$
A+3 B \stackrel{k}{\longrightarrow} 3 R+S .
$$

For the rate of reaction, written as the rate of disappearance of triglyceride, $A$ is

$$
-r_{A}=-\frac{\mathrm{d}[A]}{\mathrm{d} t}=k[A]^{m}[B]^{n} .
$$

In equation (2), $m$ and $n$ are the reaction orders with respect to triglyceride and methanol, respectively, $k$ is the reaction rate constant, and $t$ is the time. By taking mass balance on triglyceride:

$$
[A]=[A]_{o}\left(1-x_{A}\right) .
$$

In equation (3), $[A]_{o}$ is the initial triglyceride concentration and $x_{A}$ is the conversion.

Similar mass balance on methanol gives

$$
[B]=[B]_{o}-3 x_{A}[A]_{o}=[A]_{o}\left(\alpha_{B}-3 x_{A}\right) .
$$

Here, $\alpha_{\mathrm{B}}=[B]_{\mathrm{o}} /[A]_{\mathrm{o}}$
Equations (3) and (4), when substituted in equation (2), give

$$
\frac{\mathrm{d} x_{A}}{\mathrm{~d} t}=k[A]_{O}^{(m+n-1)}\left(1-x_{A}\right)^{m}\left(\alpha_{B}-3 x_{A}\right)^{n} .
$$

Or,

$$
\int \frac{\mathrm{d} x_{A}}{\left(1-x_{A}\right)^{m}\left(\alpha_{B}-3 x_{A}\right)^{n}}=k[A]_{o}^{(m+n-1)} \int \mathrm{d} t .
$$

Limits for the integral are $x_{\mathrm{A}}=0$ at $t=0$ and $x_{\mathrm{A}}=x_{\mathrm{A}}$ at $t$.

Integral has been evaluated for overall order varying from 0 to 3, for different combinations of $m$ and $n$, and the integrated form of rate equation is given in Table 1.

In equations 8 to 17, a plot of left-hand-side, a function of conversion $x_{\mathrm{A}}$ versus time $t$ would be a straight line for the appropriate $m$ and $n$, with reaction rate constant $k$ given by the slope. The temperature dependency of $k$ is well represented by Arrhenius' law, $k=A e^{-\mathrm{E} / \mathrm{RT}}$, where $E$ is the activation energy, $A$ is preexponential factor, $T$ is temperature, and $R$ is universal gas constant [46].

\section{Materials and Methods}

2.1. Chemicals and Catalysts. Croton megalocarpus oil was obtained from nuts from local trees (Kesses, Uasin Gishu, and Kenya) through solvent extraction. Analytical grade sodium hydroxide, benzoic acid, benzene, phenolphthalein, and universal indicator (maximum $\mathrm{pK}=11$ ) were obtained from Gelsup, Nairobi. Analytical grade methanol, GC standards methyl heptadecanoate, Hammett indicators (4-chloroaniline, 4-nitroaniline, 2,4-dinitroaniline, bromothymol blue) were from Sigma-Aldrich. Alkaline earth catalysts, $\mathrm{MgO}$ (99\%), Nano $\mathrm{MgO}$ (99.8\%), $\mathrm{CaO}$ (96\%), Nano $\mathrm{CaO}$ (98\%), $\mathrm{SrO}$ (99.9\%), $\mathrm{BaO}$ (97\%), of analytical grade were from Sigma-Aldrich.

\subsection{Characterization of Croton Megalocarpus Oil.} Characteristic physical properties, density, viscosity, refractive index, sulphur content, moisture content, ash, acid value, saponification value, iodine value, peroxide value, and calorific value were obtained by standard methods, and fatty acid composition was obtained by GC [5].

2.3. Characterization of Alkaline Earth Catalysts. Rehydrated $\mathrm{CaO}(\mathrm{CaO} \mathrm{RO})$ was prepared by first hydrating $\mathrm{CaO}$ with water to obtain calcium hydroxide, which was later calcined (at $700^{\circ} \mathrm{C}$ ) back to $\mathrm{CaO}$.

Microscopy: TEM analysis was conducted on a JEOL $2100 \mathrm{~F}$ TEM instrument, operated at $200 \mathrm{kV}$. The powder sample was sonicated in ethanol for $5 \mathrm{~min}$, followed by depositing the solution on a $\mathrm{Cu}$-grid with holey carbon film. The material is dispersed in ethanol using a bath sonicator to form a suspension. One or two droplets were dropped onto a holey carbon-supported copper grid and allowed to dry. TEM imaging was performed on a dry sample.

X-ray diffraction: PAnalytical XPERT-PRO diffractometer was used for X-ray diffraction. 
TABLE 1: Integrated form of rate equation (equation (7)).

\begin{tabular}{lccccc}
\hline Case & Overall order & $m$ & $n$ & Rate equation & Equation number \\
\hline 1 & 0 & 0 & 0 & {$[A]_{\mathrm{o}} x_{A}=k t$} & 8 \\
2 & 1 & 1 & 0 & $\ln \left(1 /\left(1-x_{A}\right)\right)=k t$ & 9 \\
3 & 1 & 0 & 1 & $-(1 / 3) \ln \left(\left(\alpha_{B}-3 x_{A}\right) / \alpha_{B}\right)=k t$ & 10 \\
4 & 2 & 1 & 1 & $x_{A 1} /\left(1-x_{A}\right)=k[\mathrm{~A}]_{\mathrm{o}} t$ & 11 \\
5 & 2 & 2 & 0 & $x_{A} /\left(\left(\alpha_{B}-3 x_{A}\right) \alpha_{B}\right)=k[\mathrm{~A}]_{\mathrm{o}} t$ & 12 \\
6 & 2 & 0 & 2 & $\left(1 /\left(\alpha_{B}-3\right)\right) \ln \left(\left(\alpha_{B}-3 x_{A}\right) /\left(1-x_{\mathrm{o}}\right) \alpha_{3}\right)=k$ & 14 \\
7 & 3 & 2 & 1 & $\left(1 /\left(\alpha_{B}-3\right)\right)\left[\left(\left(x_{A} /\left(1-x_{A}\right)\right)-\left(3 /\left(\alpha_{B}-3\right)\right) \ln \left(\left(\alpha_{B}-3 x_{A}\right) /\left(1-x_{A}\right) \alpha_{B}\right)\right]=k[\mathrm{~A}]_{\mathrm{o}}^{2} t\right.$ & 15 \\
8 & 3 & 1 & 2 & $\left(1 /\left(3-\alpha_{B}\right)\right)\left[\left(3 x_{A} /\left(\left(\alpha_{B}-3 x_{A}\right) \alpha_{B}\right)-\left(1 /\left(3-\alpha_{B}\right)\right) \ln \left(\left(1-x_{A}\right) \alpha_{B} /\left(\alpha_{B}-3 x_{A}\right)\right]=k[\mathrm{~A}]_{\mathrm{o}}^{2} t\right.\right.$ & 16 \\
9 & 3 & 3 & 0 & $\left(2-x_{A}\right) x_{A} /\left(1-x_{A}\right)^{2}=2 k[\mathrm{~A}]_{\mathrm{o}^{2}} t$ & 17 \\
10 & 3 & 0 & 3 & $1 /\left(\alpha_{B}-3 x_{A}\right)^{2}-1 / \alpha_{B}^{2}=6 k[\mathrm{~A}]_{\mathrm{o}^{2}} t$ & \\
\hline
\end{tabular}

2.4. Transesterification of Croton Megalocarpus Oil Using Conventional Heating. A 3-neck round bottom flask $(250 \mathrm{ml})$ fitted with a water-cooled condenser was used as a reactor. It was fitted with a mechanical stirrer and a thermometer and placed in a constant temperature water bath (WB) for studies with conventional heating. Mixing speed was $800 \mathrm{rpm}$, sufficient to eliminate mass transfer resistances. Alkaline earth catalyst samples were activated by heating under reflux with a weighed amount of methanol for one hour at the desired temperature, before the addition of Croton megalocarpus oil. The reaction was timed at this point and samples were drawn from time to time. Studies were also made using $\mathrm{NaOH}$ homogeneous catalyst for the sake of comparison between the relative yields between the two catalyst systems. The product drawn was quenched in ice to stop the reaction and made to stand to separate the oil and aqueous fractions. Oil fraction was then centrifuged for $30 \mathrm{~min}$ to remove any solid catalysts, heated at $90^{\circ} \mathrm{C}$ to remove any dissolved methanol, and analyzed by GC for total FAME [5].

2.5. Transesterification of Croton Megalocarpus Oil Using Microwave Irradiation. Round bottom flask reactor was placed in a modified domestic microwave (MW) oven (Shivaki, SMW-103, 1300W) fitted with an external magnetic stirrer (Hanna) and a Teflon ${ }^{\circledR}$ shielded thermocouple (Hanna HI9055) as a temperature sensor. Stirring was vigorous to rule out mass transfer resistances. The other procedure was similar to the one described in Section 2.4.

2.6. Study of Transesterification Kinetics. In order to study the reaction kinetics at conventional heating, studies were made at temperatures of $40,50,60$, and $70^{\circ} \mathrm{C}$, at methanol to oil molar ratio of $9: 1$, catalyst at 1 mass $\%$, and reaction lasting $3 \mathrm{~h}$; and samples were drawn at time intervals of 15 , $30,45,60,90,120,150$, and $180 \mathrm{~min}$. For microwave irradiation, reactions were carried out at 50,60 , and $70^{\circ} \mathrm{C}$, at methanol-to-oil ratio $9: 1$ and catalyst concentration of 1 mass\%; and samples were drawn at 30, 45, 60, and $90 \mathrm{~s}$. Gas chromatography was used to estimate FAME yield as given by Kumar and Kiriamiti [5]. Regression analysis was used to identify the reaction order, and the regression coefficients were used to obtain the reaction rate constant.

\section{Results and Discussion}

3.1. Croton Megalocarpus Oil Characteristics. Characteristic physical properties obtained by standard methods were as follows [5]: density (293 K) $929.2 \mathrm{~kg} \mathrm{~m}^{-3}$; kinematic viscosity $(313 \mathrm{~K}) 28.52 \mathrm{~mm}^{2} \mathrm{~s}^{-1}$; refractive index $(293 \mathrm{~K}) 1.4737$; sulphur $0.001 \mathrm{wt} \%$; moisture $0.007 \mathrm{wt} \%$; ash $0.087 \mathrm{wt} \%$; acid value $2.00 \mathrm{mg} \mathrm{KOH} / \mathrm{g}$; saponification value 192.1; iodine value $139.2 \mathrm{mg} / \mathrm{g}$; peroxide value 8.66 ; and gross calorific value $41.0 \mathrm{MJ} / \mathrm{kg}$. Fatty acid composition (mass\%) was as follows: caprylic 0.09, caproic 0.08, lauric 0.09, myristic 0.26, palmitic 8.39 , stearic 3.15 , oleic 12.16 , linoleic 70.97 , and $\alpha$-linolenic 3.89 .

3.2. Alkaline Earth Catalysts Characteristics. Pore structure, surface area, and basic strength and basicity: these properties have been reproduced in Table 2 from earlier publication [5].

Results show that alkaline earth oxides had low porosity with exception of Nano $\mathrm{MgO}$. Nano $\mathrm{MgO}$ had the highest porosity and barium oxide the least. The porosity varied as Nano $\mathrm{MgO}>$ Nano $\mathrm{CaO}>\mathrm{MgO}>\mathrm{CaO}>\mathrm{CaO}-\mathrm{RO}>\mathrm{SrO}>$ $\mathrm{BaO}$. Catalysts arranged according to basicity were $\mathrm{BaO}>$ $\mathrm{SrO}>\mathrm{Nano} \mathrm{CaO}>\mathrm{CaO} \mathrm{RO}>\mathrm{CaO}>\mathrm{Nano} \mathrm{MgO}>\mathrm{MgO}$.

Microscopy: Figure 2 gives the TEM images of the catalysts.

X-ray diffraction patterns of calcined catalysts confirmed the purity of catalyst samples.

3.3. FAME Yield. The highest yields of FAME (\%) for conventional heating for various catalysts were as follows: $\mathrm{NaOH} 98, \mathrm{BaO} 82, \mathrm{SrO} 75, \mathrm{Nano} \mathrm{CaO} 74, \mathrm{CaO} \mathrm{RO} 42, \mathrm{CaO}$ 30, Nano MgO 25, and $\mathrm{MgO}$ 20. Similar yields (\%) for microwave irradiation were $\mathrm{NaOH} 96, \mathrm{BaO} 72$, SrO 68, Nano $\mathrm{CaO}$ 55, CaO RO 20, $\mathrm{CaO} 14$, Nano MgO 2, and $\mathrm{MgO}$ 2. Results indicate that the promising catalysts giving good (>50\%) yield were $\mathrm{NaOH}, \mathrm{BaO}, \mathrm{SrO}$, and Nano $\mathrm{CaO}$. Reaction data of these catalysts are been presented here. Figure 3 gives FAME yield as a function of time and temperature for $\mathrm{NaOH}, \mathrm{BaO}, \mathrm{SrO}$, and $\mathrm{Nano} \mathrm{CaO}$ catalysts for water bath (WB) and microwave (MW) heating.

3.4. Reaction Order and Rate Constant. Kinetic data for Figure 3 were fitted into integrated forms of reaction rate equations (Table 1) to get the reaction order. For all the ten 
TABLE 2: Surface properties, basic strength, and basicity of catalysts ( $S_{\mathrm{BET}}=\mathrm{BET}$ surface area) [5].

\begin{tabular}{lcccccc}
\hline Catalyst & Pore radius (BJH desorp) $m$ & $\mathrm{~S}_{\mathrm{BET}}\left(\mathrm{m}^{2} \mathrm{~kg}^{-1}\right)$ & Solid density $\left(\mathrm{kg} \mathrm{m}^{-3}\right)$ & Porosity $\left(\varepsilon_{\mathrm{p}}\right)$ & Basic strength $\left(\mathrm{H}_{-}\right)$ & Basicity $(\mathrm{mmol} / \mathrm{g})$ \\
$\mathrm{BaO}$ & $9.88 \mathrm{E}-09$ & 1981.6 & 5720 & 0.03 & $15<\mathrm{H}_{-}<18.4$ & 0.0961 \\
$\mathrm{SrO}$ & $2.50 \mathrm{E}-08$ & 1361.1 & 4700 & 0.04 & $15<\mathrm{H}_{-}<18.4$. & 0.0841 \\
$\mathrm{Nano} \mathrm{CaO}$ & $1.13 \mathrm{E}-08$ & 24149 & 3300 & 0.18 & $11<\mathrm{H}_{-}<15$ & 0.0625 \\
$\mathrm{CaO}-\mathrm{RO}$ & $1.63 \mathrm{E}-08$ & 4470 & 3100 & 0.05 & $11<\mathrm{H}_{-}<15$ & 0.0535 \\
$\mathrm{CaO}$ & $1.71 \mathrm{E}-08$ & 6960 & 3300 & 0.09 & $11<\mathrm{H}_{-}<15$ & 0.0441 \\
$\mathrm{Nano} \mathrm{MgO}$ & $1.16 \mathrm{E}-08$ & 40830 & 3600 & 0.30 & $11<\mathrm{H}_{-}<15$ & 0.0361 \\
$\mathrm{MgO}$ & $1.07 \mathrm{E}-08$ & 19545.5 & 3600 & 0.16 & $11<\mathrm{H}_{-}<15$ & 0.0289 \\
\hline
\end{tabular}

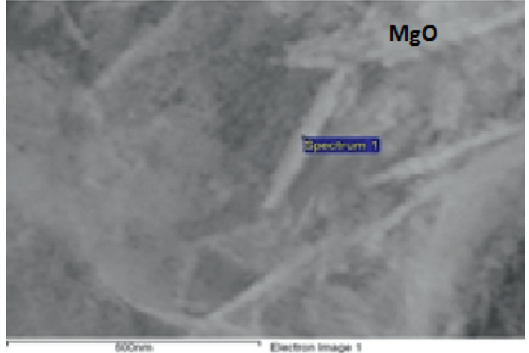

(a)

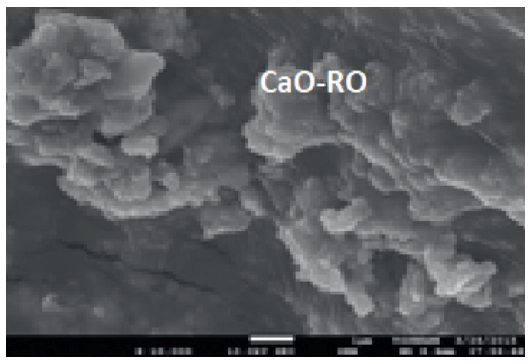

(d)

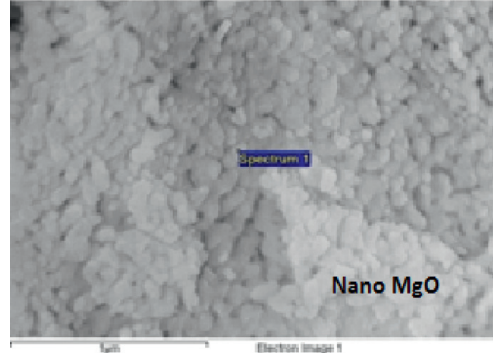

(b)

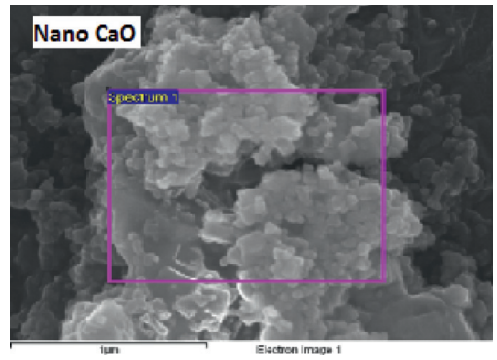

(e)

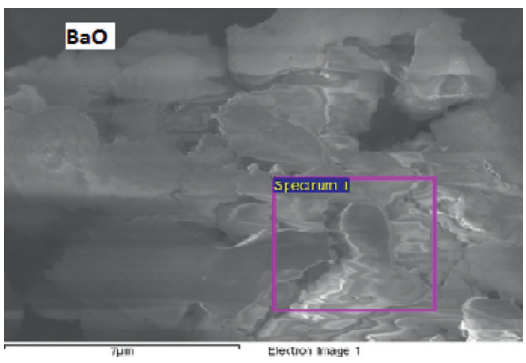

(g)

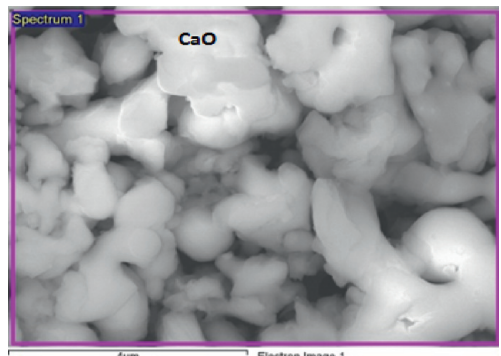

(c)

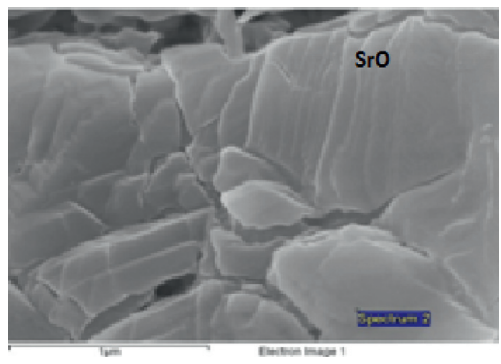

(f)

Figure 2: TEM images of catalysts (a MgO, b Nano MgO, c CaO, d CaO RO, e Nano CaO, f SrO, g BaO).

cases, $\mathrm{F}\left(x_{\mathrm{A}}\right)$ correlated with time $t$ and the coefficientof-determination $\left(R^{2}\right)$ and normalized root mean square deviation (NRMSD), obtained for a linear regression passing through the origin. Equation with the highest $R^{2}$ and lowest NRMSD at a given temperature was taken to be representing the most likely reaction order. Table 3 gives the $R^{2}$ and NRMSD for the reaction orders from zero to three, and the largest coefficient $R^{2}$ and lowest NRMSD (in bold). Table 4 gives the reaction order with respect to the two reacting species, the overall order, the reaction rate constant $(k)$, activation energy $(E)$, and preexponential factor $(A)$. For any heating mode, rates were the highest for homogeneous
$\mathrm{NaOH}$, followed by heterogeneous $\mathrm{BaO}, \mathrm{SrO}$, and Nano $\mathrm{CaO}$ catalysts. A comparison of the magnitudes of $k$ for WB to MW shows that microwave irradiation rates were higher than conventional heating, being 5 times for $\mathrm{NaOH}, 44$ for $\mathrm{BaO}, 47$ for $\mathrm{Nano} \mathrm{CaO}$, and 78 for SrO. Hence, for solid catalysts, the most active was $\mathrm{BaO}$, followed by $\mathrm{SrO}$ and $\mathrm{Nano} \mathrm{CaO}$. Microwave irradiation is a superior heating method due to higher rates, leading to shorter reaction times; and, for alkaline earth metals, the catalyst activity follows the order of basicity and is not related to specific surface area.

Overall observed reaction order ranged from first to third. For $\mathrm{NaOH}$ catalyst with microwave irradiation, the 

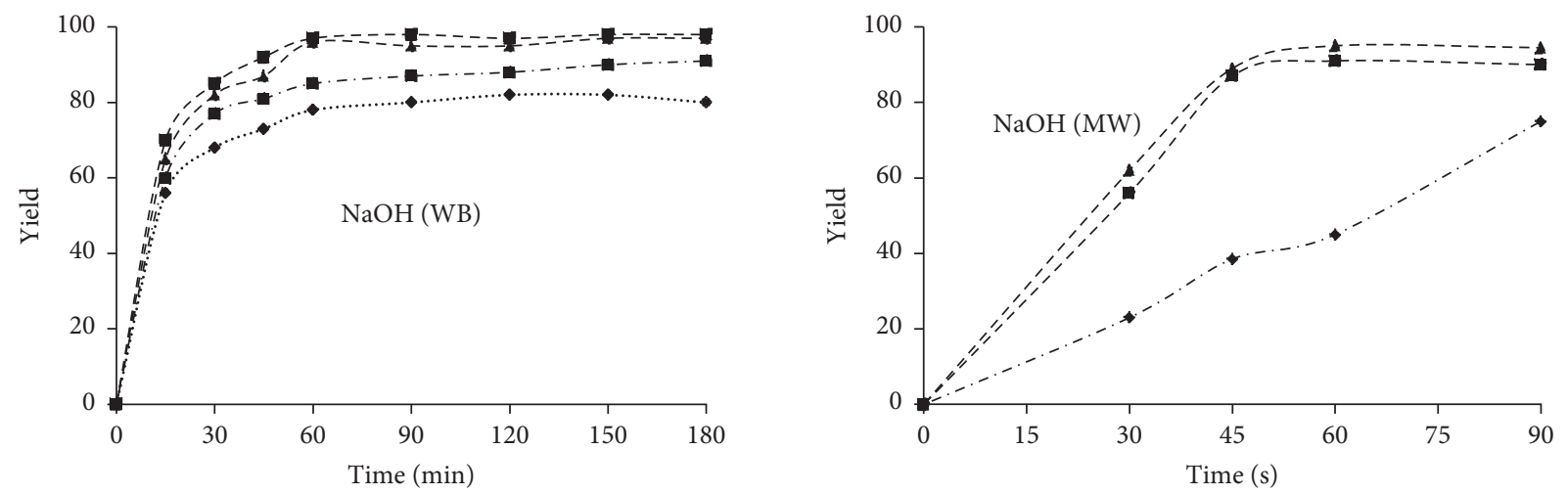

$\begin{array}{ll}\cdots-40 \operatorname{deg} C & -\neq 60 \operatorname{deg} C \\ -50 \operatorname{deg} C & -70 \operatorname{deg} C\end{array}$

$\rightarrow-50 \operatorname{deg} \mathrm{C}$

$-60 \mathrm{deg} \mathrm{C}$

- $-70 \operatorname{deg} \mathrm{C}$
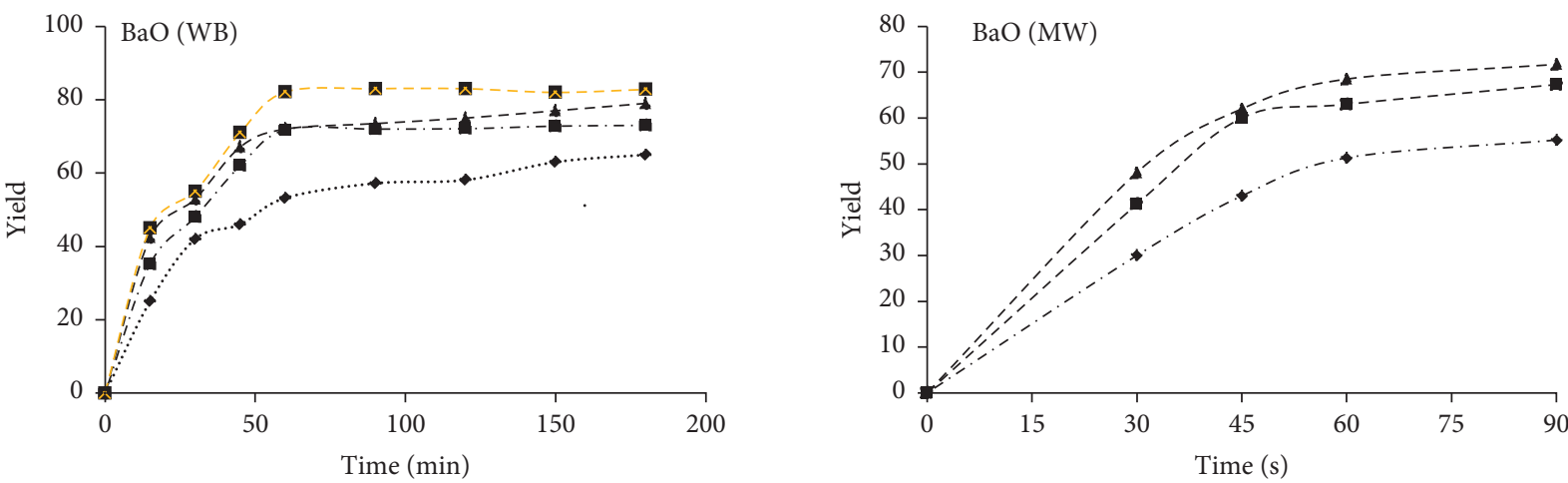

… $40 \mathrm{deg} \mathrm{C} \quad-\neq-60 \operatorname{deg} \mathrm{C}$

$\rightarrow-50 \operatorname{deg} \mathrm{C}$

- $-60 \operatorname{deg} \mathrm{C}$

- $-70 \operatorname{deg} \mathrm{C}$
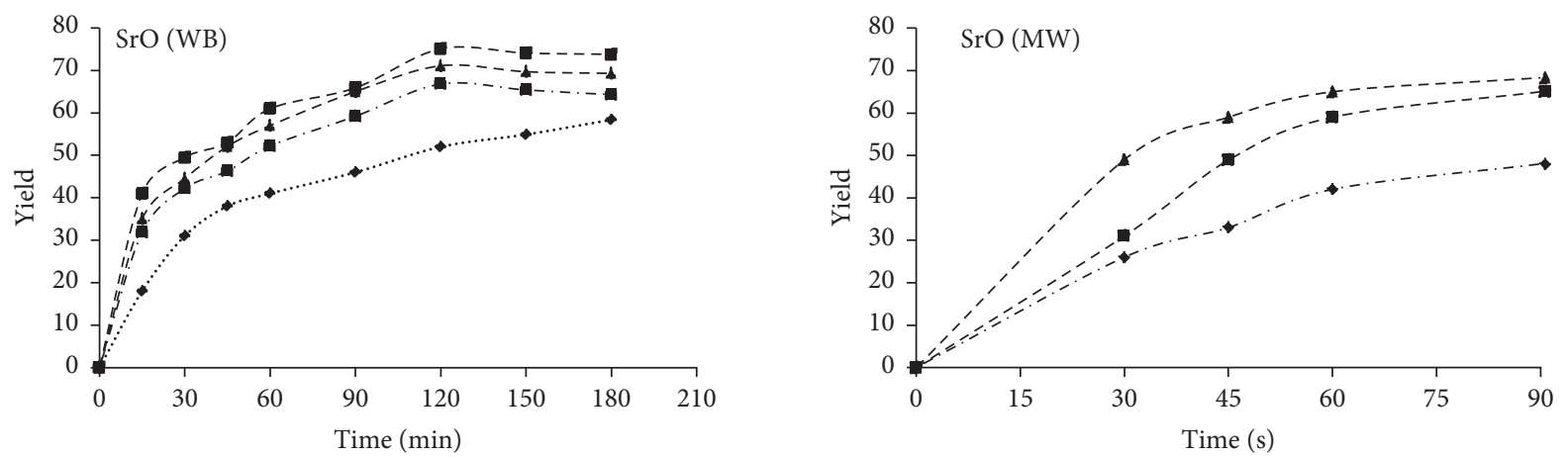
… $40 \operatorname{deg} \mathrm{C}$
- - $60 \operatorname{deg} \mathrm{C}$
$\rightarrow-50 \operatorname{deg} \mathrm{C}$
- $50 \operatorname{deg} \mathrm{C}$
- $70 \operatorname{deg} \mathrm{C}$
- $-60 \mathrm{deg} C$
-₫ $70 \operatorname{deg} \mathrm{C}$

FIgURE 3: Continued. 

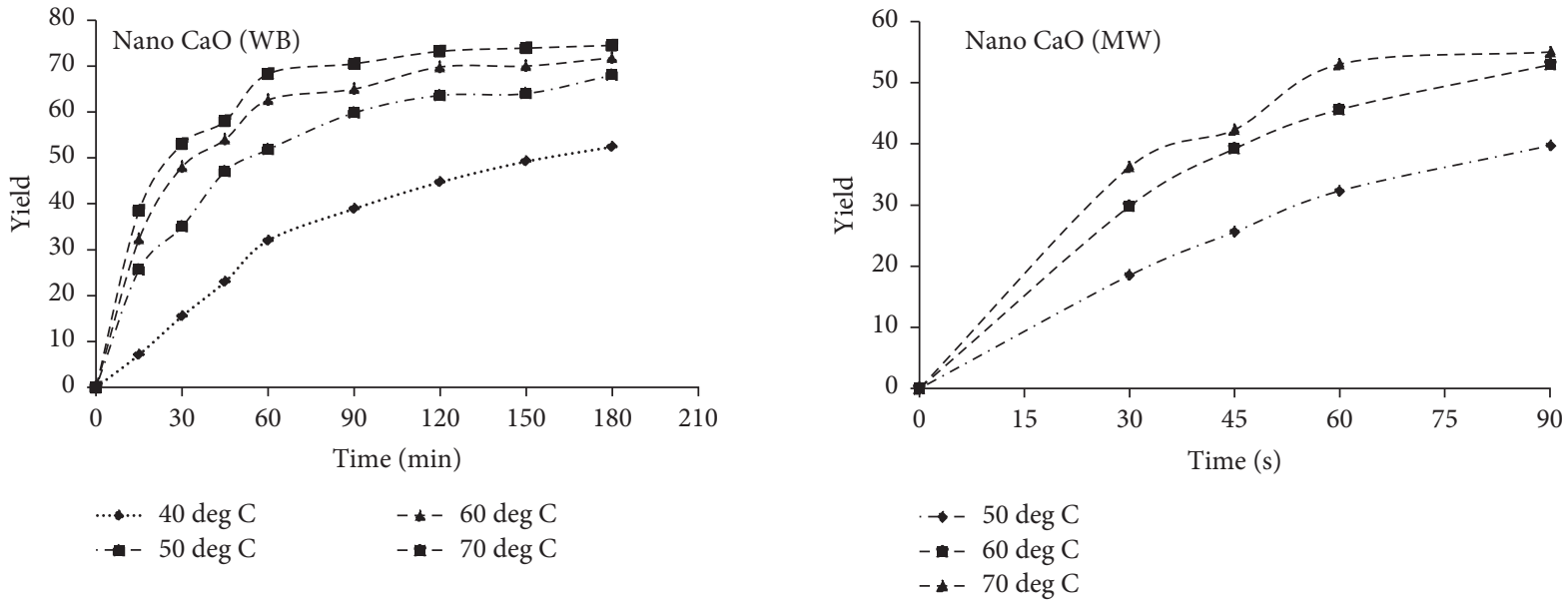

Figure 3: FAME yield as a function of time and temperature for $\mathrm{NaOH}, \mathrm{BaO}, \mathrm{SrO}$, Nano $\mathrm{CaO}$ catalysts for the water bath (WB) and microwave (MW) heating.

TABLE 3: $R^{2}$ and NRMSD (in brackets) for various catalysts and reaction orders for WB and MW heating at $70^{\circ} \mathrm{C}$ (numbers in bold refer to largest $R^{2}$ and lowest NRMSD).

\begin{tabular}{|c|c|c|c|c|c|c|c|c|}
\hline $\begin{array}{l}\text { Case } \\
(m, n)\end{array}$ & $\mathrm{NaOH}(\mathrm{WB})$ & $\mathrm{NaOH}(\mathrm{MW})$ & $\mathrm{BaO}(\mathrm{WB})$ & $\mathrm{BaO}(\mathrm{MW})$ & $\mathrm{SrO}(\mathrm{WB})$ & $\mathrm{SrO}(\mathrm{MW})$ & $\begin{array}{c}\text { Nano } \mathrm{CaO} \\
\text { (WB) }\end{array}$ & $\begin{array}{c}\text { Nano CaO } \\
(\mathrm{MW})\end{array}$ \\
\hline $1(0,0)$ & $\begin{array}{c}0.3728 \\
(0.1429) \\
\end{array}$ & $\begin{array}{c}0.7618 \\
(0.0982) \\
\end{array}$ & $\begin{array}{c}0.5041 \\
(0.1211)\end{array}$ & $\begin{array}{c}0.7923 \\
(0.0892) \\
\end{array}$ & $\begin{array}{c}0.5921 \\
(0.1041)\end{array}$ & $\begin{array}{c}0.7714 \\
(0.0944) \\
\end{array}$ & $\begin{array}{c}0.5434 \\
(0.1127)\end{array}$ & $\begin{array}{c}0.8256 \\
(0.0796)\end{array}$ \\
\hline $2(1,0)$ & $\begin{array}{c}0.6763 \\
(0.0892) \\
\end{array}$ & $\begin{array}{c}0.8533 \\
(0.0683) \\
\end{array}$ & $\begin{array}{c}0.6346 \\
(0.0981) \\
\end{array}$ & $\begin{array}{c}0.8851 \\
(0.0617)\end{array}$ & $\begin{array}{c}0.7589 \\
(0.0741)\end{array}$ & $\begin{array}{c}0.8618 \\
(0.0688)\end{array}$ & $\begin{array}{c}0.6906 \\
(0.0862)\end{array}$ & $\begin{array}{c}0.8843 \\
(0.0618)\end{array}$ \\
\hline $3(0,1)$ & $\begin{array}{c}0.4175 \\
(0.1354)\end{array}$ & $\begin{array}{c}0.7803 \\
(0.0932)\end{array}$ & $\begin{array}{c}0.5299 \\
(0.1167)\end{array}$ & $\begin{array}{c}0.8120 \\
(0.0837)\end{array}$ & $\begin{array}{c}0.6270 \\
(0.0981)\end{array}$ & $\begin{array}{c}0.7905 \\
(0.0892)\end{array}$ & $\begin{array}{c}0.5727 \\
(0.1075)\end{array}$ & $\begin{array}{c}0.8490 \\
(0.0752)\end{array}$ \\
\hline $4(1,1)$ & $\begin{array}{c}0.7175 \\
(0.0818) \\
\end{array}$ & $\begin{array}{c}0.8483 \\
(0.0785) \\
\end{array}$ & $\begin{array}{c}0.6528 \\
(0.0947) \\
\end{array}$ & $\begin{array}{c}0.9017 \\
(0.0562) \\
\end{array}$ & $\begin{array}{c}0.7900 \\
(0.0681) \\
\end{array}$ & $\begin{array}{c}0.8803 \\
(0.0630) \\
\end{array}$ & $\begin{array}{c}0.7196 \\
(0.0598) \\
\end{array}$ & $\begin{array}{c}0.8969 \\
(0.0577) \\
\end{array}$ \\
\hline $5(2,0)$ & $\begin{array}{c}0.7946 \\
(0.0609) \\
\end{array}$ & $\begin{array}{c}0.6973 \\
(0.0865)\end{array}$ & $\begin{array}{c}0.7062 \\
(0.0888) \\
\end{array}$ & $\begin{array}{c}0.9517 \\
(0.0469)\end{array}$ & $\begin{array}{c}0.8811 \\
(0.0494)\end{array}$ & $\begin{array}{c}0.9402 \\
(0.0419)\end{array}$ & $\begin{array}{c}0.8261 \\
(0.0595)\end{array}$ & $\begin{array}{c}0.9277 \\
(0.0465)\end{array}$ \\
\hline $6(0,2)$ & $\begin{array}{c}0.4650 \\
(0.1274) \\
\end{array}$ & $\begin{array}{c}0.7969 \\
(0.0884) \\
\end{array}$ & $\begin{array}{c}0.5550 \\
(0.1123) \\
\end{array}$ & $\begin{array}{c}0.8315 \\
(0.0781) \\
\end{array}$ & $\begin{array}{c}0.6620 \\
(0.0919) \\
\end{array}$ & $\begin{array}{c}0.8098 \\
(0.0839) \\
\end{array}$ & $\begin{array}{c}0.6024 \\
(0.1023) \\
\end{array}$ & $\begin{array}{c}0.8557 \\
(0.0708) \\
\end{array}$ \\
\hline $7(2,1)$ & $\begin{array}{c}0.7555 \\
(0.0694) \\
\end{array}$ & $\begin{array}{c}0.6736 \\
(0.8915) \\
\end{array}$ & $\begin{array}{c}0.9629 \\
(0.0828) \\
\end{array}$ & $\begin{array}{c}0.9580 \\
(0.0338) \\
\end{array}$ & $\begin{array}{c}0.8940 \\
(0.0452) \\
\end{array}$ & $\begin{array}{c}0.9517 \\
(0.0371) \\
\end{array}$ & $\begin{array}{c}0.8465 \\
(0.0551) \\
\end{array}$ & $\begin{array}{c}0.9444 \\
(0.0437) \\
\end{array}$ \\
\hline $8(1,2)$ & $\begin{array}{c}0.7286 \\
(0.0791) \\
\end{array}$ & $\begin{array}{c}0.8412 \\
(0.0695) \\
\end{array}$ & $\begin{array}{c}0.7778 \\
(0.0921) \\
\end{array}$ & $\begin{array}{c}0.9161 \\
(0.0511) \\
\end{array}$ & $0.81790 .0625)$ & $\begin{array}{c}0.8977 \\
(0.0574) \\
\end{array}$ & $\begin{array}{c}0.7463 \\
(0.0757) \\
\end{array}$ & $\begin{array}{c}0.9093 \\
(0.0534) \\
\end{array}$ \\
\hline $9(3,0)$ & $\begin{array}{c}0.6925 \\
(0.0692)\end{array}$ & $\begin{array}{c}0.4220 \\
(0.1108)\end{array}$ & $\begin{array}{c}0.7067 \\
(0.0892)\end{array}$ & $\begin{array}{c}0.9514 \\
(0.0394)\end{array}$ & $\begin{array}{c}0.8520 \\
(0.0523)\end{array}$ & $\begin{array}{c}0.8775 \\
(0.0438)\end{array}$ & $\begin{array}{c}0.8144 \\
(0.0987)\end{array}$ & $\begin{array}{c}0.9439 \\
(0.0490)\end{array}$ \\
\hline $10(0,3)$ & $\begin{array}{c}0.5129 \\
(0.1192)\end{array}$ & $\begin{array}{c}0.8109 \\
(0.0842)\end{array}$ & $\begin{array}{c}0.5790 \\
(0.1082)\end{array}$ & $\begin{array}{c}0.9505 \\
(0.0726)\end{array}$ & $\begin{array}{c}0.6966 \\
(0.0857)\end{array}$ & $\begin{array}{c}0.8291 \\
(0.0785)\end{array}$ & $\begin{array}{c}0.6320 \\
(0.0970)\end{array}$ & $\begin{array}{c}0.8700 \\
(0.0664)\end{array}$ \\
\hline
\end{tabular}

reaction was of first order and that with water bath was of second order. All reactions with heterogeneous catalyst indicated an overall third order, second order with respect to triglyceride, and first order with respect to methanol. For WB, a second-order kinetics has been reported for homogeneous $\mathrm{NaOH} / \mathrm{KOH}$ catalysts for transesterification of palm oil and methanol [34], sunflower oil with methanol $[35,36,38]$, sunflower oil with ethanol [37], and soybean oil with methanol [32]. For MW, literature supporting a firstorder reaction for $\mathrm{NaOH}$ catalyst is from Jain and Sharma for Jatropha curcas oil [39] and Jain et al. [40] for waste cooking oil. Singh and Fernando [19] used $\mathrm{BaO}$ for soybean oil transesterification in a high-pressure reactor and conventional heating and have reported overall third-order kinetics, second-order with respect to triglyceride, and firstorder with respect to methanol. For microwave irradiation, Patil et al. [30] report a similar order for transesterification of Camelina sativa oil on $\mathrm{BaO}$ and $\mathrm{SrO}$ catalyst. The present work is in agreement with the published work on $\mathrm{BaO}$ and SrO kinetics. No kinetic study involving Nano $\mathrm{CaO}$ has been reported. Activation energy and preexponential factor data do not show any trend. A catalyst lowers the activation energy of a reaction, but the magnitude of activation energy for a heterogeneously catalyzed reaction is not automatically 
TABLE 4: Reaction orders, rate constants, activation energy, and preexponential factor.

\begin{tabular}{|c|c|c|c|c|c|c|c|c|c|}
\hline $\mathrm{SN}$ & Catalyst & $\begin{array}{l}\text { Heating } \\
\text { mode }\end{array}$ & $\begin{array}{l}\text { Order w. r. t } \\
\text { triglyceride }\end{array}$ & $\begin{array}{l}\text { Order w. r. t } \\
\text { methanol }\end{array}$ & $\begin{array}{l}\text { Overall } \\
\text { order }\end{array}$ & $\begin{array}{c}\text { Rate } \\
\text { constant } \\
k \text { at } 70^{\circ} \mathrm{C}\end{array}$ & Units of $k$ & $\mathrm{E}(\mathrm{kJ} / \mathrm{mol})$ & A \\
\hline \multirow{2}{*}{1} & \multirow{2}{*}{$\mathrm{NaOH}$} & WB & 2 & 0 & 2 & $4.75 E-01$ & $\mathrm{~cm}^{\wedge} 3 \mathrm{~mol}^{\wedge}-1 \min ^{\wedge}-1$ & 71.3 & $3.73 E+10$ \\
\hline & & MW & 1 & 0 & 1 & $2.45 E+00$ & $\min ^{\wedge}-1$ & 51.0 & $2.68 \mathrm{E}+06$ \\
\hline \multirow{2}{*}{2} & \multirow{2}{*}{$\mathrm{BaO}$} & WB & 2 & 1 & 3 & $1.27 E-02$ & $\mathrm{~cm}^{\wedge} 6 \mathrm{~mol}^{\wedge}-2 \min ^{\wedge}-1$ & 35.4 & $3.07 \mathrm{E}+03$ \\
\hline & & MW & 2 & 1 & 3 & $5.69 E-01$ & $\mathrm{~cm}^{\wedge} 6 \mathrm{~mol}^{\wedge}-2 \min ^{\wedge}-1$ & 36.8 & $2.38 \mathrm{E}+05$ \\
\hline \multirow{2}{*}{3} & \multirow{2}{*}{$\mathrm{SrO}$} & WB & 2 & 1 & 3 & $6.19 E-03$ & $\mathrm{~cm}^{\wedge} 6 \mathrm{~mol}^{\wedge}-2 \min ^{\wedge}-1$ & 26.6 & $7.37 \mathrm{E}+01$ \\
\hline & & MW & 2 & 1 & 3 & $4.88 E-01$ & $\mathrm{~cm}^{\wedge} 6 \mathrm{~mol}^{\wedge}-2 \mathrm{~min}^{\wedge}-1$ & 46.2 & $5.67 \mathrm{E}+06$ \\
\hline \multirow{2}{*}{4} & Nano & WB & 2 & 1 & 3 & $5.65 E-03$ & $\mathrm{~cm}^{\wedge} 6 \mathrm{~mol}^{\wedge}-2 \min ^{\wedge}-1$ & 33.7 & $8.80 \mathrm{E}+02$ \\
\hline & $\mathrm{CaO}$ & MW & 2 & 1 & 3 & $2.68 E-01$ & $\mathrm{~cm}^{\wedge} 6 \mathrm{~mol}^{\wedge}-2 \min ^{\wedge}-1$ & 36.6 & $1.79 \mathrm{E}+03$ \\
\hline
\end{tabular}

accepted to be a quantitative measure of the catalytic activity. The reason for not adopting this criterion is the widespread occurrence of compensation effects [47, 48]. Transesterification reaction consisting of three consecutive reactions falls under this category. Reaction velocity constant in this case is a sum of several reaction steps, and activation energy is termed "apparent activation energy" and the preexponential factor is termed "apparent preexponential factor." In some cases, the changes in apparent preexponential factor and apparent activation energy display a linear dependency according to the Cremer-Constable relation [49].

\section{Conclusions}

Transesterification reaction kinetics of croton megalocarpus oil depends on the catalyst employed and the heating method. Observed reaction orders ranged between $1^{\text {st }}$ (for $\mathrm{NaOH}, \mathrm{MW}$ ), $2^{\text {nd }}$ (for $\mathrm{NaOH}, \mathrm{WB}$ ), and $3^{\text {rd }}$ (for $\mathrm{BaO}, \mathrm{SrO}$, Nano $\mathrm{CaO}, \mathrm{MW}$, and $\mathrm{WB}$ ). For microwave irradiation reaction, rate constants were higher by several orders as compared to those for conventional heating, due to faster reaction rates under the former. Heterogeneous catalyst activity depended on its basicity, with little relationship to the surface area. Among the catalysts studied, homogeneous $\mathrm{NaOH}$ gave the highest yield, followed by heterogeneous $\mathrm{BaO}, \mathrm{SrO}$, and Nano $\mathrm{CaO}$. Activation energy and preexponential factor data for the catalysts did not show any trend, and the compensation effect is speculated.

\section{Data Availability}

The reaction kinetics and any other data used to support the findings of this study are available from the corresponding author upon request.

\section{Conflicts of Interest}

The authors declare that there are no conflicts of interest regarding the publication of this paper.

\section{Acknowledgments}

The authors wish to acknowledge the assistance of Professor Maurice Onyango of TUT, South Africa, in catalyst characterization.

\section{References}

[1] A. Demirbas, "Progress and recent trends in biodiesel fuels," Energy Conversion and Management, vol. 50, pp. 14-34, 2009.

[2] L. Milch, Environmental Comparisons of Croton Megalocarpus vs. Other Tropical Feedstocks, Africa Biofuel With Emission Reduction (Tanzania) Ltd., Dar es Salaam, Tanzania, http:// www.africabiofuel.com/files/feedstocks.pdf.

[3] O. Kibazohi and R. S. Sangwan, "Vegetable oil production from Jatropha curcas, Croton megalocarpus, Aleurites moluccana, Moringa oleifera and Pachira glabra: assessment of renewable energy resources for bio-energy production in Africa," Biomass and Bioenergy, vol. 25, no. 3, pp. 1352-1356, 2011.

[4] B. Aliyu, B. Agnew, and S. Douglas, "Croton megalocarpus (Musine) seeds as a potential source of bio-diesel," Biomass and Bioenergy, vol. 34, no. 10, pp. 1495-1499, 2010.

[5] A. Kumar and H. K. Kiriamiti, "Optimisation of transesterification of Croton megalocarpus oil over alkaline earth catalysts using conventional and microwave irradiation by response surface methodology," Indian Chemical Engineer, vol. 2, pp. 1-11, 2020.

[6] P. Gera, S. K. Puri, and M. K. Jha, "Use of Heterogeneous Catalysts for Biodiesel Production: A Review", New Frontiers In Biofuels, pp. 370-379, Scitech Publications (India) Pvt Ltd, Chennai, TN, India, 2009.

[7] D. Y. C. Leung, X. Wu, and M. K. H. Leung, "A review on biodiesel production using catalyzed transesterification," Applied Energy, vol. 87, no. 4, pp. 1083-1095, 2010.

[8] K. Suwannakarn, E. Lotero, K. Ngaosuwan, and J. G. Goodwin Jr, "Simultaneous free fatty acid esterification and triglyceride transesterification using a solid acid catalyst with in situ removal of water and unreacted methanol," Industrial \& Engineering Chemistry Research, vol. 48, no. 6, pp. 2810-2818, 2009.

[9] P. D. Patil and S. Deng, "Transesterification of camelina sativa oil using heterogeneous metal oxide catalysts," Energy \& Fuels, vol. 23, no. 9, pp. 4619-4624, 2009.

[10] K. Narasimharao, A. Lee, and K. Wilson, "Catalysts in production of biodiesel: a review," Journal of Biobased Materials and Bioenergy, vol. 1, no. 1, pp. 19-30, 2007.

[11] B. Freedman, R. O. Butterfield, and E. H. Pryde, "Transesterification kinetics of soybean oil 1," Journal of the American Oil Chemists' Society, vol. 63, no. 10, pp. 1375-1380, 1986.

[12] R. U. Schuchardt, R. Sercheli, and M. Vargas, "Transesterification of vegetable oils: a review," Journal of the Brazilian Chemical Society, vol. 9, no. 1, pp. 199-210, 1998. 
[13] M. K. Lam, K. T. Lee, and A. R. Mohamed, "Homogeneous, heterogeneous and enzymatic catalysis for transesterification of high free fatty acid oil (waste cooking oil) to biodiesel: a review," Biotechnology Advances, vol. 28, no. 4, pp. 500-518, 2010.

[14] A. Kumar, S. O. Osembo, S. S. Namango, and H. K. Kiriamiti, "Heterogeneous basic catalysts for transesterification of vegetable oils: a review," in Proceedings of the 2012 Mechanical Engineering Conference on Sustainable Researchand Innovation, JKUAT, vol. 4, pp. 59-68, Juja, Kenya, May 2012.

[15] Y. H. Taufiq-Yap, H. V. Lee, R. Yunus, and J. C. Juan, "Transesterification of non-edible Jatropha curcas oil to biodiesel using binary $\mathrm{Ca}-\mathrm{Mg}$ mixed oxide catalyst: effect of stoichiometric composition," Chemical Engineering Journal, vol. 178, pp. 342-347, 2011.

[16] G. Arzamendi, E. Arguinarena, I. Campo, S. Zabala, and L. M. Gandia, "Alkaline and alkaline-earth metal compounds as catalysts for the methanolysis of sunflower oil," Catalysis Today, vol. 133-135, pp. 305-313, 2008.

[17] J. F. Puna, J. F. Gomes, M. J. N. Correia, A. P. Soares Dias, and J. C. Bordado, "Advances on the development of novel heterogeneous catalysts for transesterification of triglycerides in biodiesel," Fuel, vol. 89, no. 11, pp. 3602-3606, 2010.

[18] Y. Liu, E. Lotero, J. G. Goodwin, and X. Mo, "Transesterification of poultry fat with methanol using $\mathrm{Mg}-\mathrm{Al}$ hydrotalcite derived catalysts," Applied Catalysis A: General, vol. 331, pp. 138-148, 2007.

[19] V. B. Veljkovic, O. S. Stamenkovic, Z. B. Todorovic, M. L. Lazic, and D. U. Skala, "Kinetics of sunflower oil methanolysis by calcium oxide," Fuel, vol. 88, pp. 1554-1562, 2009.

[20] M. Kouzu, T. Kasuno, M. Tajika, Y. Sugimoto, S. Yamanaka, and J. Hidaka, "Calcium oxide as a solid base catalyst for transesterification of soybean oil and its application to biodiesel production," Fuel, vol. 87, no. 12, pp. 2798-2806, 2008.

[21] M. Kouzu, T. Kasuno, M. Tajika, S. Yamanaka, J. Hidaka, and J. Hidaka, "Active phase of calcium oxide used as solid base catalyst for transesterification of soybean oil with refluxing methanol," Applied Catalysis A: General, vol. 334, no. 1-2, pp. 357-365, 2008.

[22] M. Kouzu, S.-y. Yamanaka, J.-s. Hidaka, and M. Tsunomori, "Heterogeneous catalysis of calcium oxide used for transesterification of soybean oil with refluxing methanol," Applied Catalysis A: General, vol. 355, no. 1-2, pp. 94-99, 2009.

[23] S. Gryglewicz, "Rapeseed oil methyl esters preparation using heterogeneous catalysts," Bioresource Technology, vol. 70, no. 3, pp. 249-253, 1999.

[24] A. Kawashima, K. Matsubara, and K. Honda, "Acceleration of catalytic activity of calcium oxide for biodiesel production," Bioresource Technology, vol. 100, no. 2, pp. 696-700, 2009.

[25] S. Babak, H. Iman, and A. Z. Abdullah, "Alkaline earth metal oxide catalysts for biodiesel production from palm oil: elucidation of process behaviours and modelling using response surface methodology," Iranian Journal of Chemistry and Chemical Engineering, vol. 32, no. 1, pp. 113-126, 2013.

[26] C. R. V. Reddy, R. Oshel, and J. G. Verkade, "Roomtemperature conversion of soybean oil and poultry fat to biodiesel catalyzed by nanocrystalline calcium oxides," Energy Fuels, vol. 20, no. 3, pp. 1310-1314, 2006.

[27] P.-L. Boey, G. P. Maniam, S. A. Hamid, and D. M. H. Ali, "Crab and cockle shells as catalysts for the preparation of methyl esters from low free fatty acid chicken fat," Journal of the American Oil Chemists' Society, vol. 88, no. 2, p. 283, 2011.
[28] N. Viriya-empikul, P. Krasae, B. Puttasawat, B. Yoosuk, N. Chollacoop, and K. Faungnawakij, "Waste shells of mollusk and egg as biodiesel production catalysts," Bioresource Technology, vol. 101, no. 10, pp. 3765-3767, 2010.

[29] P. Khemthong, C. Luadthong, W. Nualpaeng et al., "Industrial eggshell wastes as the heterogeneous catalysts for microwaveassisted biodiesel production," Catalysis Today, vol. 190, no. 1, p. 112, 2012.

[30] P. Patil, V. G. Gude, S. Pinappu, and S. Deng, "Transesterification kinetics of Camelina sativa oil on metal oxide catalysts under convention and microwave heating conditions," Chemical Engineering Journal, vol. 168, no. 3, pp. 1296-1300, 2011.

[31] E. Martinez-Guerra and V. G. Gude, "Transesterification of used vegetable oil catalyzed by barium oxide under simultaneous microwave and ultrasound irradiations," Energy Conversion and Management, vol. 88, pp. 633-640, 2014.

[32] H. Noureddini and D. Zhu, "Kinetics of transesterification of soybean oil," Journal of the American Oil Chemists' Society, vol. 74, no. 11, pp. 1457-1463, 1997.

[33] D. Darnoko and M. Cheryan, "Kinetics of palm oil transesterification in a batch reactor," Journal of the American Oil Chemists' Society, vol. 77, no. 12, pp. 1263-1267, 2000.

[34] T. Leevijit, W. Wisutmethangoon, G. Prateepchaikul, C. Tongurai, and M. A. Allen, "Second order kinetics of palm oil transesterification," in Proceedings of the Joint International Conference on Sustainable Energy and Environment (SEE), pp. 277-281, Hua Hin, Thailand, December 2004.

[35] G. Vicente, M. Martínez, J. Aracil, and A. Esteban, "Kinetics of sunflower oil methanolysis," Industrial \& Engineering Chemistry Research, vol. 44, no. 15, pp. 5447-5454, 2005.

[36] M. E. Bambase Jr., N. Nakamura, J. Tanaka, and M. Matsumura, "Kinetics of hydroxide-catalyzed methanolysis of crude sunflower oil for the production of fuelgrade methyl esters," Journal of Chemical Technology \& Biotechnology, vol. 82, no. 3, pp. 273-280, 2007.

[37] A. V. Marjanović, O. S. Stamenković, Z. B. Todorović, M. L. Lazić, and V. B. Veljković, "Kinetics of the base-catalyzed sunflower oil ethanolysis," Fuel, vol. 89, pp. 665-671, 2010.

[38] O. Stamenkovic, M. Lazic, Z. Todorovic, V. Veljkovic, and D. Skala, "The effect of agitation intensity on alkali-catalyzed methanolysis of sunflower oil," Bioresource Technology, vol. 98, no. 14, pp. 2688-2699, 2007.

[39] S. Jain and M. P. Sharma, "Kinetics of acid base catalyzed transesterification of Jatropha curcas oil," Bioresource Technology, vol. 101, no. 20, pp. 7701-7706, 2010.

[40] S. Jain, M. P. Sharma, and S. Rajvanshi, "Acid base catalyzed transesterification kinetics of waste cooking oil," Fuel Processing Technology, vol. 92, no. 1, pp. 32-38, 2011.

[41] G. Kafuku, K. T. Tan, K. T. Lee, and M. Mbarawa, "Noncatalytic biodiesel fuel production from Croton megalocarpus oil," Chemical Engineering Technology, vol. 34, no. 11, pp. 1827-1834, 2011.

[42] T. F. Dossin, M.-F. Reyniers, R. J. Berger, and G. B. Marin, "Simulation of heterogeneously $\mathrm{MgO}$-catalyzed transesterification for fine-chemical and biodiesel industrial production," Applied Catalysis B: Environmental, vol. 67, no. 1-2, pp. 136-148, 2006.

[43] T. Dossin, M. Reyniers, and G. Marin, "Kinetics of heterogeneously MgO-catalyzed transesterification," Applied $\mathrm{Ca}$ talysis B: Environmental, vol. 62, no. 1-2, pp. 35-45, 2006.

[44] A. K. Singh and S. D. Fernando, "Reaction kinetics of soybean oil transesterification using heterogeneous metal oxide 
catalysts," Chemical Engineering Technology, vol. 30, no. 12, pp. 1716-1720, 2007.

[45] A. A. Reefat, S. T. El Sheltawy, and K. U. Sadek, "Optimum reaction time, performance and exhaust emissions of biodiesel produced by microwave irradiation," International Journal of Environmental Science \& Technology, vol. 5, pp. 315-322, 2008.

[46] O. Levenspiel Levenspiel, Chemical Reaction Engineering, John Wiley \& Sons, New York, NY, USA, 1972.

[47] J. M. Thomas and W. J. Thomas, Introduction to the Principles of Heterogeneous Catalysis", Academic Press, New York, NY, USA, 1st edition, 1967.

[48] G. Marbán and L. del Río, "Tentative explanation for the kinetic compensation effect in doped catalysts," Kinetics and Catalysis, vol. 54, no. 4, pp. 463-468, 2013.

[49] A. Kumar and S. S. Namango, "Compensation effect in transesterification kinetics of Croton megalocarpus oil using heterogeneous alkaline earth catalysts," IRJET, vol. 4, no. 3, pp. 1-5, 2017. 